\title{
Haptic Transgression. The Horror of Materiality in Kurt Kren's Films
}

\author{
Bori Máté \\ Eötvös Loránd University (Budapest, Hungary) \\ E-mail: barbatrukk1@gmail.com
}

\begin{abstract}
The article investigates two seemingly conflicting critical approaches of haptic and transgressive cinema, which emerged along with the corporeal turn in film studies, in the late 1990s and early 2000s. While haptics operates with undistinguishable figures and demands extreme closeness and an active caressing gaze, transgression is usually seen from a distance and subverts the social, political and ethical order. The paper attempts an examination of the Austrian avant-garde filmmaker Kurt Kren's Actionist films and enlightens how these two opposing strategies can be present together. Giving a detailed analysis of the films, the article describes an expanded definition of Linda Williams's body genres, in order to create a new category of horror: the horror of materiality.
\end{abstract}

Keywords: haptics, transgression, Kurt Kren, avant-garde, Viennese Actionism.

The primary aim of this article is to examine, through the terms of haptic and transgressive cinema, a few selected works from the oeuvre of the Austrian avant-garde filmmaker Kurt Kren, which he made in collaboration with the Viennese Actionists Otto Mühl and Günter Brus. In contemporary film theory the phenomenological approach has become more and more popular as theorists like Vivian Sobchack, Barbara Creed, Linda Williams and Laura U. Marks highlighted the spectator's body as a key element of the cinematic perception and interpretation; Marks has also made the haptic aspects of certain experimental films prominent ${ }^{1}$ (see Marks 2000, and also 2002). While phenomenological approach is frequently used to examine not only contemporary films which show certain sensitivity towards sensuality and the material (for an examination of

1 Marks's (2000) claims are based on her own encounters with artists' media. She describes in a phenomenological approach films, videos, digital media, independent television, performances and visual arts made by experimental media makers. 
early cinema, see Dahlquist et al. 2018), it still does not seem to be a permanent approach regarding experimental cinema. Even though this kind of increased sensitivity is not quite a contemporary phenomenon in experimental film, it is rarely applied persistently by theorists to analyse the different sensuous examples of experimental cinema. The cultural, artistic environment of the 1960s along with the corporeal turn strongly inspired the creation of such works as Carolee Schneemann's Fuses (1965), Barbara Rubin's Christmas On Earth (1963) or the aforementioned Actionist films of Kurt Kren. These works seem to attract the haptic and phenomenological approach so intensely that we may find the use of these methods unavoidable and most relevant. The different forms of transgression have become quite important subjects for contemporary film theorists such as Martine Beugnet and Joel Gwynne. Nevertheless, the acknowledgement and examination of these transgressive aspects were already present in the American filmic discourse of the 1960s, especially in relation to experimental films of the underground scene (Osterweil, 2014). This observation seems to be confirmed by Amos Vogel's book, Film as a Subversive Art (1974). The founder of the avantgarde cine-club Cinema 16 made these subversive aspects the main topic in his book, which is an especially significant work for my thesis because of its special emphasis on experimental cinema. Through experimental films, the book shows the diversity of transgression, which often originates from cultural memories, taboos and traumas, and manifests in violence or liberating sexuality.

Otto Mühl and Günter Brus, two artists of the Viennese Actionsts originally invited Kurt Kren to document the actions they performed, but Kren, instead of just documenting, created his own work of art. Regarding the perceptive aspects, a phenomenological approach might also address the question of the border-line position of these films, as they originally documented live performances, while the resulting films themselves may be screened in a cinematic environment, and also exhibited in museums or galleries. The experience of watching these performances may be powerful but the perception itself is fragmented by nature. As a result of constant selection, the attention always shifts between spectacles, salient for the viewer. Therefore I suggest that watching someone else's selected "expressed experience" (Sobchack, 1992) in a movie theatre does not make the experience necessarily unfamiliar, however it is much more intense and it extinguishes the extant distance of the performance due to its formal radicalism. Exhibiting experimental films raises another question of perception. In this situation, it is important to make the distinction between a spectator and a viewer, due to their reflection to perceptual differences. In a gallery, in the audience there 
are spectators, whose perception is non-linear: they are not immovable, and they perceive artworks both in a bigger curatorial context and in each other's context. In this completely changed milieu, it is questionable that a constantly looped experimental film remains a film, at all, or becomes something new. Accordingly, the haptic aspects of Kren's Actionist films can work most effectively in a dense cinematic environment, where there are viewers in the audience (not only spectators who are passing by), who have fixed positions, and perceive the films linearly (from the beginning to the end).

Kren's works can be seen as haptic cinema not only because they are experimental films characterized by a quite radical film form which contains serial editing, close-ups and extreme close-ups, but also because of their objects and forms which come from a highly materialistic, performative tradition. After World War II, fine artists like Otto Mühl, Günter Brus, Hermann Nitsch and Rudolf Schwarzkogler decided to amplify the duo of art and revolution, starting with the creation of the idea of material painting. Its real essence was that they did not want to represent or reproduce anything from nature but to attract the attention to what was actually visible on the surface: the fabric. Being involved in such a happening-like event, urged an intense sensory feeling in both the creator and the viewer. As Paul Sakoilsky puts it in his article, Breaking Out of the Reality Asylum. Thoughts on Hermann Nitsch and the Orgies Mysteries Theatre (2010), these artists were devoted to the belief that an absorbed sensual awareness of our surroundings automatically broadens consciousness and in my opinion, this is related to the concept of touch. During an action, the sensory, invigorating methods were absolutely intuited and directly seen by the audience. According to Nitsch, pouring, spraying, spreading over and throwing red liquid evokes an intense sensory arousal (2010, 4-13). Eventually, they planned to turn the place of the action into a sort of theatre of orgies, to make the whole event similar to a ritual with paint, flesh, blood and intestines. Viennese Actionism grew from this realization (Nitsch 2010, 14-22). While the Actionists subverted the tradition of fine art and concept art utterly and joyfully, Kren carried out their notion on the filmic level of the action and resulted in a total disruption of the film form. By doing so, he presented a completely fresh attitude towards the portrayal of an object in a cinematographic act. Therefore the other term I intend to use is related to the subject and the nature of these captured performances, which are mostly transgressive. Even if being haptic does not necessarily imply transgression itself especially because being able to constitute something as transgressive often requires the use of optical images, most of Kren's Actionist films are subversive 
since they violate the usual practice in almost every possible way. Since in these cases transgression plays a significant role, I would also like to include this aspect in my analysis. Before going into deeper examinations, I find it necessary to point out a few possible incongruences regarding the terms in question. While haptic cinema can be closely related to Marks's definition, transgressivity has still remained a characteristic lacking any accurate contemporary theorization in the field, therefore in this article it will be interpreted variously depending on the different authors. ${ }^{2}$ In the following section, I will introduce the theoretical basis of haptics and transgressive cinema, as well as define the terms I will use later on, in order to confer the criteria of my later examinations.

\section{Haptics}

Haptic perception usually refers not only to sensation by touching but to even more: it carries some kind of physical activity, as well. It is a kind of sensation that has highly stimulating functions and one that makes a connection between the visual and the rest of the senses by involving them in many ways. As Vivian Sobchack claims one does not experience a movie only through the eyes but the whole body takes part in the process of perception and interpretation by using the information of the carnal knowledge of his/her sensorium (Sobchack 2004, 53-84). Haptic visuality as a perfect tool to achieve this kind of bodily activity, involves the body in the process of seeing to a greater extent, thus, the sensual experience happens primarily through tactility and kinesthetics. As Marks points it out - based on the observations of art historian Alois Riegl which he made in relation to the haptic style of ancient Egyptian art and the optical style of Roman art -, haptic visuality is contrasted with optical visuality because it presumes the observation of the subject from a very short distance, which makes identification hardly possible. Through haptic visuality one can experience touch not merely on the surface of their body, but in a more sensuous way it can also be captured inside the body itself. As a matter of fact, haptic images encourage and invite a bodily relationship between the viewer and the image by being multisensory. They are able to create - as Marks says - a "dynamic subjectivity" between them $(2002,3)$.

Riegl, essentially a curator of textiles, adopted a close and tactile way of looking which strongly assisted - as Laura Marks writes in Touch. Sensuous Theory and

2 Although it is indispensable to identify and reflect on this problem, it will not be further discussed in the article, since it does not jeopardize or significantly affect the results of my analysis. 
Multisensory Media - "the play of the eyes among non- or barely figurative textures" (2002, 4). Gilles Deleuze and Félix Guattari allocate haptic as a "smooth space" in contrast to "striated space." It is a space that has to be moved in an endless allusion to the immediate environment. According to them, the confined spaces - similarly to Riegl's close way of looking, as Marks points it out - are driven by haptic perception, which deals with their particularity. Through haptic perception, the haptic critic drives the smooth space by being engaged with glimpsed objects and ideas and by revealing the possible connections between them. In terms of hermeneutics, they give up the control over understanding. Instead of decoding and identifying they fuse with the material by moving on the surface of the object, almost touching and scanning it with their eyes. Accordingly, visuality is completed with hearing, touching, smelling, tasting and also the sensation of motion.

As Thomas Elsaesser and Malte Hagener (2010) also claim in their book Film Theory: An Introduction through the Senses, there is a well apprehensible relationship between the spectator's body and the images on the screen. There is "a cinematic space that is both physical and discursive" $(2010,4)$ which makes the encounter between the film and the viewer, cinema and body possible. The viewers take part in the film experience, the event itself, the components of which - such as bodies, objects or even the different surroundings on the screen - communicate with and reflect on each other through their surfaces, distances, textures, optical or even bodily markers. Alongside the strong physical attendants - for instance, the senses of vision, tactility and sound, the diversity of perceptions (which are or at least many of them are based on philosophical issues) -, the temporality of action and awareness are present, as well. They are as crucial to cinema as they are to the spectator. During the experience, the spectator is both a participant and an observer (Elsaesser and Hagener 2010, 3-13).

As cinema is not essentially verbal, film makes meaning through its materiality, bringing forth a unity between the perceiver and the object. Correlating with this materiality, but apart from Elsaesser and Hagener, Marks raises the possibility of thinking about film as skin in her book The Skin of the Film: Intercultural Cinema, Embodiment, and the Senses (2000). Skin itself traverses and repositions the relation between inside and outside, between Self and Other. In cinema, the transformation and transgression between these very same things make the way cinema works similar to the working of the body. Introducing this prospect might make it a bit easier to understand the tactility of vision. Haptic visuality provides the spectator the opportunity to "touch" a film with their eyes. If we accept Marks's hypothesis, this perception of film as skin means that film is as 
conductive and susceptible as human skin. As a result, the experience of the film among spectators can be pictured as several encounters of skins, which mark each other and leave shared footprints. Many of the works that have these same peculiarities recall individual and cultural memories by bringing the allurement to materialize knowledge and experiences of the senses to being. Haptic images urge the observers to react, give a response to what they see. It is a personal, embodied way of acting; it assists the progress of obtaining "sensory impressions" (Marks 2000, 2). According to Marks, haptic images bring attention to the physical organization of sensory experience (2000, 1-23).

In many instances, haptic cinema goes back to the concept of early cinema, more accurately to the idea of Tom Gunning's "cinema of attractions" $(2002,7)$. This explains a truly embodied response in which the illusory image allows the identification with the action onscreen and gives a chance to an instantaneous bodily reaction to the screen. Accordingly, haptic criticism turns back to the concerns of theorists like Béla Balázs or Dziga Vertov, who stressed the importance of the relationship between the spectator's body and the film image. Haptic cinema works with images which occasionally signify figures but then draw off and stop showing them fully. In other cases, they move so close to the camera that nothing is visible anymore. Haptic cinema does not make figures entirely distinguishable, and this fact will become apparent in Kurt Kren's films. Indeed, it puts the object into question so the viewers' own imagination must decide what they are seeing. Haptic images pull the observer too close to see correctly, and this is what Marks calls erotic $(2002,15)$. Hence, she suggests that a haptic image itself is erotic (2002, 13-14). However, this is not always the case, and will address this when discussing Kren's films. Although these films contain haptic images which allow viewers to give up their need of understanding and identifying the object of visual erotics to keep its unknowability, in the case of the respective films I find it rather difficult to set aside the constant presence of "abject" and the lack of immersion which inhibit the spectators from giving in to the eroticism of haptic images.

Since embodiment and sense perception have moved into a more and more important place for many artists, haptic visuality appears in cinematic genres such as experimental film. The main goals and basic attitude of experimental cinema, mainly rooted in classical avant-garde movements, make these artworks perfect subjects for "haptic criticism." Most of the experimental films are non-commercial and non-narrative; they turn the attention towards the apparatus, the materiality and film form (Kuenzli 1996, 13-27). They use the medium in a reductive way and have a close connection with other art forms. Both the formal strategies of 
experimental cinema aimed at the viewers' perception, and the narrative elements connected to sexual representation - occurring in these films in some kind of experimental approach - are present in the films that will be analysed here.

\section{Transgression and Subversion in the Cinema of Sensation}

Transgression in film, as Joel Gwynne gives the brief definition of the term in Transgression in Anglo-American Cinema: Gender, Sex and the Deviant Body (2016, 1-9), aims to cross certain socially constructed boundaries and to go beyond tradition in both narrative form and narrative function. And even though haptic cinema and transgression do not always go together, transgression cannot be separated from what Martine Beugnet (2007) calls the "cinema of sensation" because it relies greatly on the medium's corporeal, materialistic and sensational dimensions. Transgressive and subversive images consistently have a certain tactility. The cinematic discovery of a sensual, incorporated understanding of realism can be expressed in a mutual connection of "subjective body and objective world" $(2007,32)$. The films that are going to be discussed here, frequently show a sort of bodily abjection. Therefore, Julia Kristeva's idea of the "abject" is not avoidable in relation to Kren's Actionist films. Kristeva's term is connected to both transgression and the body (skin and touch). On one hand it does not recognize any boundaries, standards or principles of behaviour. It intentionally subverts identity, system and order. On the other hand, she also includes in this category the different kinds of body fluids such as urine, faeces, saliva or tears. These are not really part of the body, neither are completely separate from it, which puts them into a similar category as skin is. Barbara Creed refers to Kristeva's term in her book The Monstrous Feminine: Film, Feminism, Psychoanalysis (1993) in connection with horror films; in general terms, abjection is a mechanism of removing the non-human from the human or separating the entirely formed subject from the partially formed one. This and the importance of rituals, by which societies are able to revive their first contact with the abject and then exclude it, are both quite close to the original Actionist performances and the films of Kren (1993). Watching Brus's close-ups of self-mutilation with a razor in 10/65 Selbstverstümmelung, or Mühl as he serves his penis on a plate as a Christmas meal in 9/64 O Tannenbaum, not only endorses the viewers to regain contact with the abject but also provides an opportunity to confront with the questions of processing social traumas or moral and ethical matters. 
The triggering of a clearly tangible visceral reaction in the observer often takes place as a result of watching graphic violence or sex, or any violently digressive exchange between subject and object. This drives the whole action toward the range of abjection. As Beugnet (2007) suggests in relation to French film, the cinema of sensation balances between pleasure and abjection by arousing serious ethical issues. The transgression of boundaries supervenes stepping over the border of order and disorder, uniformity and heterogeneity, public and private. Avant-garde filmmakers discussed here experiment with the physicality of film and from time to time adopt subversive elements - sometimes from other genres, such as pornography or horror - which build on sensory shock. By inducing a state of shock, they disapprove of and judge the currently existing status quo. By this token, the transgression and subversion of the experimental films in question are determined to confront the spectators with ethical matters and social taboos, and of criticizing the currently existing social model.

Introducing Amos Vogel's thoughts on this matter, which he presents in his book Film as a Subversive Art (1974), helps to strengthen the case of subversion. He goes back much further in the past, looking for causes of the emergence of subversion in arts, photography and cinema. He introduces the Freudian notion of taboo and, extricating the term's layers of meaning, uses it as a potential explanation. Reflecting on the taboo that forbids watching or touching certain things deemed "unholy," it is possible to create a system of firmly controlled and enforced rules of order and social supervision by naming the taboos themselves (objects, acts, persons etc.). As for the object of the taboo, in Vogel's interpretation, one views it as infectious and as something that can transmit its "virus" to those who break the rule. As humans have always been attracted to objects and acts that were forbidden, these embody both the abhorrence and the enchantment at the same time. Therefore, the fear of contagion becomes as great as the fear of temptation. Connecting the above-mentioned ideas to cinema, the way the taboo image affects spectators can be understood by examining their physiological and emotional reactions. Cinema makes it possible to witness real death, torture, the act of giving birth, and sex. Watching such scenes, viewers can share the feeling of the exciting guilt of the voyeur which goes together with the fear of punishment: they take a look at something they do not have the right to see. By this token, I propose for further consideration that the films discussed below embody these tabooed images which are able to bring on the aforementioned complex position of the voyeur. 


\section{6/64 Mama und Papa}

The first film Kren shot was 6/64 Mama und Papa, ${ }^{3}$ a document of one of Mühl's material actions. It was projected on $16 \mathrm{~mm}$ film, like all the Actionist films, and was originally shot silent and on coloured film. Some details are not entirely visible but rather impressionistic due to the chosen style of editing, though we can see a woman and a man interacting with each other in some familiar and less familiar ways. Through a detailed examination of this film, I aim to point out its connection with Beugnet's concept of the cinema of sensation, by emphasizing its corporeal, materialistic and sensational dimensions. The performers, man and woman, are both covered with various materials. The material that covers their whole body seems similar to clay; it is lutulent, thick and distorts their body so much that they look almost non-human. This clayish substance does not only cover their body but almost everything around them and they never come out of it. Even though the male character gives the impression of passivity, he is the director of the happening; whatever she does, it has a great impact on him, he becomes the leading man. Everything is about him, his desire and pleasure. The woman offers her breast to him, lets him touch her and probably goes down on him. Although the viewer has the impression of watching oral sex, due to the structure of montage it is not quite evident; it remains an associative series of images. The two characters imitate the various roles of being a mother, a father, and a child or having a sexual intercourse and even giving birth. We can see a close-up of the woman's vagina while the same lutulent, clayish material that covers them is pouring out of it, and right after this we can see the man's head between her legs seemingly imitating a newborn baby.

Referring to Stan Brakhage's Window Water Baby Moving (1959), I would suggest that in these two films - despite their salient differences - something very similar happens: in 6/64 Mama und Papa the characters invest themselves in the roles of mother and father and imitate the action of giving birth; while in Brakhage's film, he filmed himself and his wife and the actual birth of his first child. We also see close-ups of the woman's vagina, but instead of clay pouring from it, the baby is born. [Figs. 1-2.] The two films also show similarities in the editing style and use of composition. Since Brakhage's camera eye is the "mind's eye" (Osterweil 2014, 94), he records what he actually sees, and not what he is

3 In the titles of his films, Kren always uses two numbers: the first one refers to the film's place in the chronological order of his works, the second one specifies the year of production. 
trained to see. ${ }^{4}$ Therefore the images are more impressionistic and abstract than concrete. Watching the labour of his wife, he catches the otherwise unrevealed functions of a body giving birth. The upside-down, repeated and sometimes canted footage is combined with more direct images of the body, such as closeups of his wife's face, belly or vagina. The increased tactility of these images evokes exceedingly strong bodily reactions in the spectators. What is more, the fact that such events had not been filmed so explicitly before - except for medical training films - makes this work of art excessively subversive as well.

The transgressiveness of Brakhage's film is obvious by revealing a completely natural event which was considered taboo at the time. Kren perverts this very same organic process: on the one hand because it is a taboo, on the other, showing it like this, in an outrageously shocking form, it is an even bigger taboo. It becomes something we do not have the right to see but excites us, however, this voyeuristic excitement is combined with the feeling of shame and a certain fear of punishment (Vogel 1974, 310). In the same way, by foregrounding the materialistic aspects and the sensuous values of these films, Kren brings bodily abjection close to the spectator. These films are also undoubtedly haptic with their frequently repeated close-ups and extreme close-ups that confront the viewer with the harsh materiality revealed in such a perspective. This makes the recognition of the images almost impossible. Focusing strongly on the interacting surfaces and the material, distorts what Brakhage calls "the man-made laws of perception" (1963, 20). This method encourages a new way of experience that builds up in the viewer during the screening. Although Brakhage exploits an extremely intimate moment, he still preserves something honest and fragile from the whole event, therefore he seems to be an almost poetic documentarist artist compared to Kren.

In contrast to the scenes described above, there is another group of sequences in 6/64 Mama und Papa, where the woman is passive, sometimes posing as a model, growing stiff as a sculpture or just lying down helplessly while the man paints her body and throws diverse pulverulent and fluid materials at her. While she is still naked, the male character is wearing ceremonious clothes for this part, acting as a real master of ceremony. Instead of the earth-like colours of the previous sequences, the most dominant colours here are red, green, white and yellow. He splodges her body with red, green and white paint that looks like flour; he pours milk and other liquids on her, then feathers fall down and stick to

4 When it comes to visual compositions, he suggests that one senses images as if one were dreaming, remembering things or becoming aware of colours and conjectural figures after closing one's eyes (see Brakhage 1963). 
the liquids that cover the woman's body. What makes the whole event's feast-like nature stronger is that it seems like the woman is placed on top of a table and the man, with a knife in his hand, is cutting vegetables onto her naked body. She is the main dish, surrounded by all the bounty in this grotesque feast. Decorated with a red flower that is seen sometimes in her posteriors or her genitalia, she is a mother, a sexual object and the main dish at the same time. Laying her on an astounding altar she is offered as a sacrifice for fertility which manifests itself in the different kinds of materials poured into and pouring out of the orifices.

Here I would like to mention Linda Williams's (1991) idea of the corporeality of spectators and her concept of the so-called "body genres," which she originally applied to Hollywood mainstream narrative genre films. She discusses three genres - horror, melodrama and pornography - which culturally belong to the lower end of the hierarchy of film genres. The films she analyses expose the body while it experiences intense, uncontrollable emotions, they show the human body in its most inarticulate manifestations dealing with body fluids. They violate the basic rules of aesthetic by eliminating the distance between spectator and the work (cf. Elsaesser and Hagener 2010, 124-145). Although the films I examine here are not genre films, the phenomena she describes is quite similar to the experience generated by Kren's works. Despite of its strong presence in the three genres listed above, this experience is not genre specific, it rather relies on the appearance of certain themes and the following of particular formal strategies. Accordingly, the aforementioned works of Kren can be considered body films, which operate through the visceral sensation of horror and a sort of monstrous pornography. Thus, what we can see here is an interesting mixture of body horror and pornographic elements where the raging material eventually conquers the people who fail to defend themselves. The sight of these bodily reactions and violations of the body, on the one hand, and the use of serial editing, close-ups and extreme close-ups which enhance the hapticity of the images, on the other, have a similar effect to what Williams describes as: "an apparent lack of proper aesthetic distance, a sense of over-involvement in sensation and emotion.” (Williams 1991, 5.)

This performance mirrors the critical and somewhat parodistic attitude of the Viennese Actionists - to be exact, that of Otto Mühl - to the body's natural processes and the diverse spectrum of gender roles, which are built in social conscience and are held as deep as crass taboos. In 6/64 Mama und Papa - as a matter of fact, this stands for all the Actionist films - this aspect is combined with the unrestrained filmmaking attitude of Kurt Kren. As stated above, Kren was asked by Mühl to film his actions. Mühl wanted him to document the event carefully so it would show 
the whole happening as it was performed in a certain place at a certain time. It should have simply mediated the Actionists' motivation and concept of fine art but not contain an additional layer of someone else's activity. What actually happened here was that Kren took control into his own hands while he was filming these actions, "undermined this effort to make an autonomous film out of the footage" (Hamlyn, Payne, and Rees 2016, 252) and presented them in an unexpected way.

The camera goes so close to his subject that it dissolves in the material and nothing else remains but the impenetrable texture itself, then it suddenly steps back and gives a wider view for a second, but this is such a short time that it becomes lost in the turmoil of images. Kren rarely lets us actually see what happens; the action is rather built up from impressions, so it can never be complete. Whereas he keeps going closer and closer, he holds a distance between the viewer and the subject. As a result of the frequently used close-ups and extreme close-ups, the spectators are never connected to what they see on the screen, at least not in a traditional way. It is quite discernible that the actions themselves were highly tactile, and through the chosen montage technique, the director enhances the tactility of the original performance and makes it more passionate, aggressive, erotic, subversive and dynamic. He uses his mathematically compiled serial editing style, familiar from his early structural films. The rapid, single frame sequences are merged with quick shot/counter-shot sequences, thus the spectators are not connected to a story or a protagonist (as in a traditional film viewing) but a connection is established between the material itself and the observer's body. Kren uses the footage to build up his own ornamental-organic order of the scenes that is far-removed from any chronological order or cause-and-effect relation between the shots. With this method, he abstracts every potentially recognizable aspect of the subjects by converting them into almost geometric figures or the semblance of action paintings and gesture art revealing an extreme sensitivity towards form and materiality.

\section{Chauvinism, Orgy and Animal Instincts: 7/64 Leda mit dem Schwan and 9/64 O Tannenbaum}

In the following films - which were also recordings of Mühl's actions -, 7/64 Leda mit dem Schwan and 9/64 O Tannenbaum, it becomes more and more evident how he transforms these performances. The 7/64 Leda mit dem Schwan, ${ }^{5}$

$5 \quad$ This film was never really completed because the model, quoting Kurt Kren, was "pissed off” by the possibility of having sexual intercourse with a live swan. Kren used some sequences from Mama und Papa to fill the film (cf. Hamlyn, Payne, and Rees 2016). 
as the title shows, is based on the Greek mythological story, which is the target of Mühl's cynical parody. The material action does not borrow anything divine from mythology, only a questionably moral, profane aspect of it. Although, according to the story the swan should be Zeus, it does not make an attempt to impregnate the woman, who lets the animal circulate around her and step on her body while it is covered with feathers and a red liquid, which Mühl constantly pours on her. Even if this chauvinistic performance, resembling porn made with animals, is happening right in front of one's eyes, viewers see a series of highly graphic, abstract images. Though Kren amplifies the haptic and subversive characteristics of the actions, he also alienates them from themselves and aestheticizes them.

The same can be noticed in 9/64 O Tannenbaum, which is a radical, impetuous criticism of the Christmas celebration. Its transgressivity greatly relies on crossing socially constructed boundaries and - as all the films discussed here on going beyond narrative form and function. Under the Christmas tree, instead of presents, there is a dining table, which is full of food and there is a naked man in the middle of the whole installation. His body is covered with pieces of the dishes and red paint. This scene is similar to the one in 6/64 Mama und Papa: to the viewer it feels like the course of events joins a huge orgy as part of a sacrifice on an altar. It is not just food they serve but a woman's breast and a man's penis, along with eggs. These sequences are broken off with scenes where a naked woman stands in front of a white canvas and a man pours paint of various colours on her, imitating the act of action painting. In this way, the images of the woman's body covered with paint with the canvas behind become similar to abstract paintings. The style of frame by frame editing transforms the film into a collection of highly graphic, abstract, gesture-like and impressionistic pictures with which Kren reveals the harsh and aggressive ambience of the performance and highlights its thick materiality with consecutive close-ups. The power of these films is partly gained from the vibration of colours that has an intense effect, appealing to the deeply hidden animal instincts of humankind. This is an important component of the film's mechanism and at the same time a feature that makes Otto Mühl's films so different from Günter Brus's actions.

In order to make more precise observations on these works, I chose to watch the original copies of these films in Top Kino, a small cinema in Vienna. In a cinematic environment, where one can encounter the images through the surface of the huge screen, it became quite evident how the viewers can take part in a film experience both as a participant and an observer, as Elsaesser and Hagener suggest (2010). Haptic visuality is not simply manifested in the close-ups of 
the rugged surfaces of body parts but in the tactile materiality of the celluloid as well. Watching the films in the cinema, I could see why Marks thinks about film as it is similar to skin and how haptic theory is connected to the idea of cinema of attractions. As an observer I was positioned to be involved in the act I was watching onscreen, and this situation made me give an immediate bodily reaction to the images. Haptics and transgression work together in these films. These recorded happenings involve nude men and women who are participating in real sexual acts which often turn into sexual violence. The images directly attack the spectator's defence mechanism and morals. This subversive gesture evolves in its encounter with the haptic images. It is transformed and enriched by the precarious material of the celluloid.

\section{Fragile Impressions: 8/64 Ana}

Kren started to film the actions of Günter Brus after Otto Mühl asked him to do it or, as Kren remembers it, after Mühl "pushed him" to do it (Hamlyn, Payne, and Rees 2016, 201). ${ }^{6}$ Their first film was $8 / 64$ Ana. This work happens to be a quite personal one because Ana was Brus's wife and they were the only participants in the action. This originally silent, black and white film suits - if not adapts - the action painting style of Brus, who usually ran through a hanging white paper with a black paint brush $(2016,201)$. Indeed, something very similar can be seen in the second half of the film as well.

This and most of Brus's actions are in sharp contrast with those of Mühl. The pure aggression and overly concentrated erotic chauvinism which pervades Mühl's material actions and intends to prey upon the darkest sides of human nature, where the definition of taboo is not interpretable, is lacking from almost all of Brus's actions, or at least it is articulated in a different way. As far as 8/64 Ana is concerned, it is a very haptic but a less transgressive piece. The plot of the action is hardly explainable due to the film form, though it seems that it is a recorded performance of action painting where not only the paper, wall or canvas but also the human body is a carrier of paint, as Brus tries to capture rugged, brisk gestures and fractures of movement. The spectators have to rely upon their impressions much more than in the case of 6/64 Mama und Papa. It is truly expressive how the naked, painted figure of Ana and Brus is shown with

$6 \quad$ Since Mühl and Brus were friends and Brus became extremely depressed because he did not have the chance to get exposure for his actions, Mühl asked Kren to film some of Brus's actions, as for them, the films functioned as adverts too (Hamlyn, Payne, and Rees 2016). 
the reverse shots of objects, such as the different parts of a bicycle, becoming geometric forms and graphic patterns in front of the lenses, using close-ups and extreme close-ups. This beautifully smooth fragility of the image gives an extremely lyrical ${ }^{7}$ aspect to its abstract expressionism, which is familiar from the contrasted imagery and exaggerated visuality of the German Expressionist film The Cabinet of Dr. Caligari (Robert Wiene, 1920). The rapidly edited, sharp graphic forms of the film make the images look like cubist paintings, though the basic concept of Actionist art had nothing to do with Cubism. In the case of 8/64 Ana, the haptic aspect of the celluloid gets a much more emphatic role. As a result of using a very low-light-sensitive film for shooting, the images of fast moving figures became painting-like.

At this point I would like to get back to Marks's ideas connected to the erotic, which she describes as something that derives from the oscillation between the optic and the haptic, the movement between distance and closeness. It can also be described as the loss of visual control caused by haptic images and limited visuality to let ourselves become one with the surface instead. But it is also apprehensible - on a phenomenological basis where the spectator actively takes part in the process of cinematic perception - in the intersubjective relation between viewer and film image (cf. Marks 2002, 12-20). Although these characteristics are detectable on the visual level of most of the Actionist films of Kren, it is only 8/64 Ana in which the erotic, as outlined by Marks, is really effective. To have a true impact, eroticism needs a certain level of immersion. The rhythm of editing and the constant presence of abjection in other films alienates the spectator and results in a lack of immersion, a loss of the erotic aspects of haptic images. If they achieve anything, it is more like what Gaylynn Studlar calls "masochistic identification" $(2002,18)$ in which, as Marks puts it, it is possible that the film viewers even give in to a literally shimmering surface, which in this case is the material itself, rather than identifying with characters. In contrast, the slower editing style and haptic images of $8 / 64$ Ana enable the viewer the immersion they need to be engaged with the surface and arouse eroticism. This way, one gets the chance to lose themselves as subjects and be opened and impressionable to the other.

$7 \quad$ Lyrical in this context does not refer to P. Adams Sitney's (2014) concept of lyrical film. It rather regards Brus's sensitive, almost poetic approach to the object.

8 Although she distinguishes between Studlar's theory which is based on the Lacanian psychoanalytic model and her phenomenological approach which aims to understand embodied spectatorship, she also acknowledges that haptic visuality has some of the qualities mentioned above. I think that the aspects of masochistic identification I was referring to before can be seen in the films Kren made in collaboration with Mühl even without exchanging the phenomenological examination with a psychoanalytical one. 


\section{The Darkest Moments: 10/65 Selbstverstümmelung}

Their next film was 10/65 Selbstverstümmelung in which there is only one person: Brus. Although the Actionist films of Kren are documentaries (as they record performances), because of the individual artistic program of Kren these films formally diverge from classical documentaries. 10/65 Selbstverstümmelung has a central place in this spectrum: besides its experimental aspects, it still keeps elements of a more classical thinking, therefore it is slightly closer to a traditional documentary film. The only subject of this keenly documented selfmutilation $^{9}$ is the artist himself. At the same time, Kren does not want to utilize the stimulating power of the colours here either, so this, too, is a black and white film. Its strength lies elsewhere: with its slower rhythm it lets the spectator closer to the subject and lets them sympathize with him. In contrast with 8/64 Ana, it is both highly transgressive and haptic, but the observers do not simply get involved by feeling what is happening on their own skin but by partly identifying themselves with Brus. The restrained pain and suffering mediated by the film makes one scream along with the silent howling of the artist. His body is covered in a white, thick clayish material. With the help of close-ups, the viewer can feel how it is spreading around his body while he is crawling on the floor in his great agony and is flaying his skin with bare hands. [Figs. 3-4.] He is a live sculpture. In his darkest moment, he turns against himself and starts to truncate his own body with knives, razors, crowbars, scissors and he stabs drawing pins in his chest and chin, placing them in a straight line. Although the film does not deal with body fluids explicitly, it is strongly connected to Kristeva's (1980) idea of abject, which also implies self-abjection. This overwhelming, tactile experience of self-terror closely connects this work to the sensation of horror. The monstrosity of both the self and the material unbreakably weighs on him and due to the sensuality of the images, on the viewer as well. Through shaky camera movements circling around Brus's body, Kren captures the fragility of this extreme state of mind. Although the director sometimes slows down to prolong the involvement in the event, he also preserves something with his fast editing style, so when he gets to the emotionally exaggerated points the imagery becomes radically expressionist. He constantly interchanges focused and unfocused shots, unusual compositions and jump cuts, and breaks off the chronological order of the action.

9 The title, Selbstverstümmelung, means self-mutilation. 


\section{Conclusion}

In this analysis of Kren's Actionist films, I tried to point out how the co-operation of subject and film form can enhance haptic aspects, and how easily the haptic and the transgressive can be connected in the wide range of the cinema of sensation. During my research I had the chance to watch the original copies of Kurt Kren's Actionist films at a screening in Vienna, where I experienced how powerful and outstanding these works are, and how they affect the spectator's body and mind. It only became evident to me how wonderfully detailed these pictures really are by watching the films in a small theatre. It is not only the subject, the action itself that operates with materiality but we perceive the texture of the celluloid, the 16 $\mathrm{mm}$ film as a carrier as well. The partly distorted images carry a tactile materiality of their own. Kren's basically Structuralist editing process merges the crushed, fragmented pieces into one expressionistic parade, which makes the experience mostly impressionistic to the observer. Kren does not simply document the event, but by keeping some kind of distance and adding his own characteristic, personal style, reflects on it and the film itself becomes an interpretation.

Besides the sensuality of the images, the content of these films is extremely transgressive. Being placed on the border of pleasure and abjection, the continual violation of social boundaries, the offense against the either secular or religious laws of the society by portraying violent sexuality, distorted and naked bodies, body fluids, self-mutilation, perverted religious holidays and gender roles combined with the chosen film form make the Actionist films wonderful examples of the oscillation of haptics and transgression. The Actionist attitude, in essence, subverts the laws and processes of nature. The Actionists avoid all sorts of dignity. What happens here is that Kren does not show the subject of the performance but the material. The material always comes first. To this end, he tears it apart until it stops being an action. He abstracts but also highlights and enhances until he raises the whole thing into aesthetic heights. The actions are unvarnished and brutal, but the disturbing and the disgusting things appearing on the screen also acquire a picturesque quality. The imagery becomes haptic to such an extent that these experimental documentaries turn into breathtaking body horrors.

Kren is closely related to Brakhage by the similar perception they create in their films. Brakhage claims in his book Metaphors on Vision that "man-made laws of perception, or compositional logic" should not rule the eye $(1963,20)$. The spectator's experience of the variety of intangible objects, continual movements and uncountable colours should be mirrored on the screen. As a result, viewers 
perceive the images as they perform the dance of lights and colours on their eyelid. Even though there is no strong connection between Kren and Brakhage when it comes to the matter of the spectator's experience, the Austrian filmmaker created something similar in his Actionist films. At the same time Kren, in contrast to Brakhage, makes the material transcendent, not natural. Emphasizing the material so much, Kren draws a line between human and non-human. He shows his subjects as if they were in a state of constant metamorphosis. ${ }^{10}$ He points out the crisis or loss of identity, questioning the relation between subjectivity and body and also the consequences of embodiment.

\section{References}

Beugnet, Martine. 2007. Cinema and Sensation. French Cinema and the Art of Transgression. Edinburgh: Edinburgh University Press.

Brakhage, Stanley. 1963. Metaphors on Vision. New York: Film Culture Inc.

Creed, Barbara. 1993. The Monstrous Feminine. Film, Feminism, Psychoanalysis. London, New York: Routledge.

Dahlquist, Marina, Doron Galili, Jan Olsson, and Valentine Robert, eds. 2018. Corporeality in Early Cinema: Viscera, Skin, and Physical Form. Indianapolis: Indiana University Press.

Elsaesser, Thomas. 1996. Dada/Cinema? In Dada and Surrealist Film, ed. Rudolf E. Kuenzli, 13-27. Cambridge, Mass.: The MIT Press.

Elsaesser, Thomas and Malte Hagener. 2010. Film Theory: An Introduction through the Senses. New York, London: Routledge.

Gwynne, Joel, ed. 2016. Transgression in Anglo-American Cinema. Gender, Sex and the Deviant Body. New York/Chichester, West Sussex: Wallflower Press.

Kristeva, Julia. 1980. Powers of Horror. An Essay on Abjection. New York: Columbia University Press.

Marks, Laura. 2000. The Skin of the Film. Intercultural Cinema, Embodiment, and the Senses. Durham/London: Duke University Press.

Marks, Laura. 2002. Touch. Sensuous Theory and Multisensory Media. Minneapolis/London: University of Minnesota Press.

Nemes Z., Márió. 2017. Metamorfózis és technoemésztés. Ovidius és a poszthumán elméletek [Metamorphosis and Techno-Metabolism: Ovidius and the PostHuman Theories]. Ókor vol. 14, no. 3: 28-63.

10 Some of the ideas of posthumanism compared by Márió Nemes Z. (2017, 28-36) to Ovid’s Metamorphoses may also be noticeable in Kren's works. 
Osterweil, Ara. 2014. Flesh Cinema. The Corporeal Turn in American Avantgarde Film. Manchester/New York: Manchester University Press.

Plunkett, Daniel. 2016. Interview with Kurt Kren. In Kurt Kren: Structural Films, eds. Nick Hamlyn, Simon Payne, and A. L. Rees, 201. Bristol, Chicago: Intellect. Sakoilsky, Paul. 2010. Breaking Out of the Reality Asylum. Thoughts on Hermann Nitsch and the Orgies Mysteries Theatre. Galerie Zimmermann Kratochwill Catalogue vol. 8: 14-22.

Sitney, P. Adams. 2014. The Cinema of Poetry. New York, Oxford: Oxford University Press.

Sobchack, Vivian. 1992. The Address of the Eye. A Phenomenology of Film Experience. Princeton/New Jersey: Princeton University Press.

Sobchack, Vivian. 2004. What My Fingers Knew. The Cinesthetic Subject, or Vision in the Flesh. In Carnal Thoughts. Embodiment and Carnal Image Culture, 53-84. Berkley/Los Angeles/London: University of California Press.

Tscherkassky, Peter. 2016. Interview with Kurt Kren. In Kurt Kren: Structural Films, eds. Nick Hamlyn, Simon Payne, and A. L. Rees, 252. Bristol, Chicago: Intellect.

Williams, Linda. 1991. Film Bodies: Gender, Genre, and Excess. Film Quarterly vol. 44, no. 4: 5 .

\section{List of Figures}

Figures 1-2. In 6/64 Mama und Papa, after seeing an extreme close-up of a sort of clayish material pouring out of a woman's vagina, we can see a man's face between the woman's legs, covered with the same material. In another scene of the film, there is a naked woman whose body is painted by a man during a feastlike event.
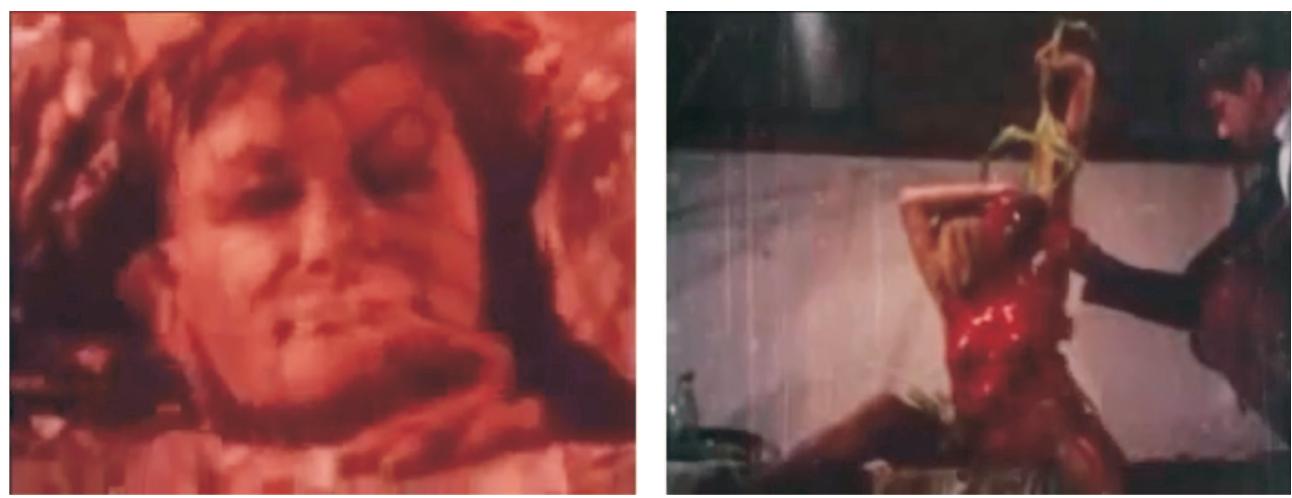
Figures 3-4. 8/64 Ana is a play with light and texture. In some of the scenes of 10/65 Selbstverstümmelung, Brus imitates to skin himself. Through the use of extreme close-ups, Kren captures the monstrosity and the horror of the event.
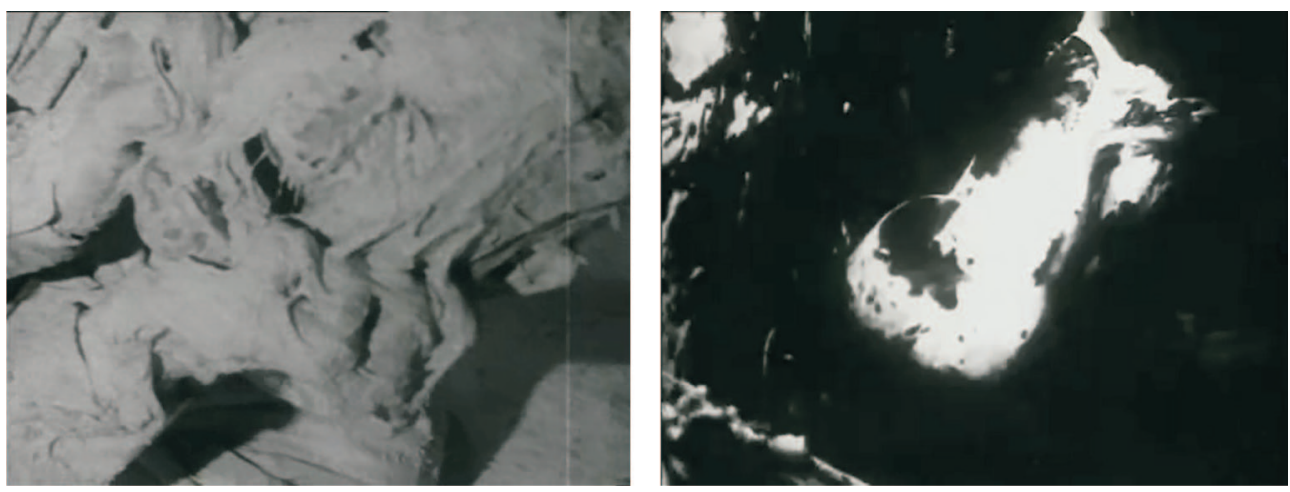